\section{Awareness, knowledge and attitudes of dental students in Yeditepe University Faculty of Dentistry towards individuals with HIV/ AIDS}

\section{Yeditepe Üniversitesi Diş Hekimliği Fakültesi öğrencilerinin HIV/ AIDS konusundaki farkındalıkları, bilgi düzeyleri ve tutumları}

\section{Dt.Murat Günbatan}

Istanbul University, Faculty of Dentistry, Department of Oral and Maxillofacial Surgery, İstanbul Turkey

\section{Dt. Berk Tolonay}

Istanbul University, Faculty of Dentistry, Department of Restorative Dentistry, İstanbul Turkey

\section{Assoc. Prof. Ceyda Özçakır Tomruk}

Yeditepe University, Faculty of Dentistry, Department of Oral and Maxillofacial Surgery, İstanbul Turkey

\section{Assist. Prof. Gonca Duygu Çapar}

Trakya University, Department of Oral and Maxillofacial Surgery, Faculty of Dentistry, Edirne, Turkey.

Received : 16 November 2015

Accepted : 19 February 2016

\section{Corresponding author:}

Assist. Prof. Gonca Duygu Çapar

Department of Oral and Maxillofacial Surgery, Faculty of Dentistry, Trakya University, Edirne, Turkey. Trakya Üniversitesi Rektörlüğü Balkan Yerleşkesi 22030, Edirne, TURKEY

Email: duygu_gonca80@hotmail.com

Tel: 0 (284) 2364551

\section{SUMMARY}

Aim: The main objective of this study was to evaluate the dental students' knowledge and awareness about HIV/ AIDS, transmission routes of HIV/AIDS, diagnosing tests, body fluids contaminated by HIV and oral symptoms of AIDS. A secondary aim was to assess the need for additional education about HIV/AIDS.

Materials and Methods: A questionnaire including 77 questions was used to evaluate the dental students' knowledge levels, awareness and attitudes towards HIV/ AIDS(n:250). Kruskal Wallis test, Mann Whitney U test, Continuity (Yates) Correction, Chi square test and Fisher Exact Chi square test were used for statistical analysis of data. $p<0.05$ was set significant.

Results: Overall, the response rate was 90.9\%. The mean age of the students were 21.66 years. Among the respondents the level of knowledge of risk groups (94\%) and transmission routes was high (85.7\%). The knowledge level of HIV diagnosing tests exceptELISA, were low (63.5\%). All of the students answered correctly the blood as a body fluids containing HIV virus. However, their knowledge level about saliva, breast milk, cerebrospinal fluid and feces were low (52.5\%). Regarding intraoral manifestations, the fifth grade students had significantly higher knowledge than the first grade students respectively, (95.3\% and 15.3\%). The majority of the students $(90.8 \%)$ thought that each patient should be considered potentially infections. Most of the students (77.8\%) were concerned about being infected with HIV by their patients. $81.6 \%$ of the students thought that their knowledge was not adequate, and $87.2 \%$ of the students need further education

Conclusion: According to these findings, efficacious education programs should be prepared to establish positive attitudes to HIV/AIDS patients, especially for the preclinical students.

Key Words: AIDS, HIV, dental students, awareness, knowledge

\section{ÖZET}

Amaç: Bu çalıșmanın amacı, Yeditepe Üniversitesi Diş Hekimliği Fakültesi öğrencilerinin, HIVIAIDS açısından risk grubunda olan bireyleri belirlemek, HIV/AIDS'in olası bulaş yolları, HIV/AIDS'in teşhis ve doğrulanmasında kullanılan testler, HIV'nin bulunabileceği vücut sIvlları, ve AIDS'in ağız içi belirtileri ile ilgili bilgi düzeylerini saptamak, bilgiye ulaşım yollarını belirlemek, AIDS hastalarına karşı tutum ve görüşlerini, tedavi etmedeki yeterliliklerini ve farkındalıklarını değerlendirmektir.

Gereç ve Yöntem: Yeditepe Üniversitesi Diş Hekimliği Fakültesi'nde, 250 öğrenciye, HIV/AIDS bilgi düzeyleri, AIDS hastalarına karșı tutum ve görüșleri konusundaki 77 sorudan 
oluşan anket formları dağıtıldı. Verilerin istatistiksel analizinde Kruskal Wallis test, Mann Whitney U test, Continuity (Yates) Correction, ki kare test ve Fisher Exact ki kare test kullanıldı. Veriler $\mathrm{p}<0,05$ anlamlıık düzeyinde değerlendirildi.

Bulgular: Ankete katılım oranı \%90,9 ve katılan öğrencilerin yaş ortalaması 21,66 idi. Öğrencilerin HIV/ AIDS risk grubundaki bireyler (\%94) ve bulaş yolları $(\% 85,7)$ konusunda bilgi düzeyleri oldukça yüksekti. ELISA dışındaki HIV/AIDS tanı ve doğrulama testleri hakkındaki bilgi düzeyleri düşüktü (63,5\%). Ankete katılan öğrencilerin hepsi HIV'in bulunabileceği vücut sıvılarından kanı doğru cevapladı. Ancak, tükürük, anne sütü, serebrospinal sıvı ve ter hakkındaki bilgi düzeyleri düşüktü (\%52). 5.sınıf öğrencilerinin HIV/AIDS'in ağız içi belirtileri konusundaki bilgi seviyeleri $(\% 95,3)$ birinci sınıf öğrencilerinden yüksektir (\%15,3). Öğrencilerin büyük çoğunluğu $(\% 90,8)$ her hastayı potansiyel enfeksiyöz olarak kabul etmekte idi. Öğrencilerin çoğu (\%77,8) hastaları tarafından enfekte edilmekten endişelenmekteydi. Öğrencilerin \%81,6'sı HIV/AIDS hakkındaki bilgilerini yetersiz görmekte, \%87,2'si ise HIV/ AIDS hakkında ilave eğitim almak istemektedir.

Sonuç: Diş hekimliği öğrencilerinin HIV/AIDS karşı farkındalıklarını arttırmak için düzenli olarak eğitim verilmeli ve öğrenci derslerinin bilgi düzeyini artırmada en etkili yöntem olduğu göz önüne alınırsa 1. ve 2. sınıf öğrencilerine daha fazla önem verilmelidir.

Anahtar Kelimeler: AIDS, HIV, bilgi düzeyi, tutum, diş hekimliği öğrencileri

\section{INTRODUCTION}

Acquired Immune Deficiency Syndrome (AIDS) is one of the most challenging health problems in the world In December 2012, World Health Organization (WHO) reported that a total of 35.3 million people lived with HIV / AIDS all over the World, of them 32.1 million were adults of them 17.7 million female. ${ }^{1}$ It is estimated that number of patients with AIDS will increase enduringly because of adolescents taking high potential risk, remaining unmindful of protection and insufficient institutions providing services to young people. In Turkey, Ministry of Health reported that 6802 people infected with HIV /AIDS while there are only 1 case and 1 carrier (Ministry of Health in Turkey, Registry and Statistics, 2013. Of these cases, 80\% are between 1549 years of age and it is stated that primary transmission route is heterosexual contact (46.1\%) ${ }^{2}$. Because HIV can be easily spreaded via direct contact with blood, the risk of being infected is very high in dental practice. Since 1988, WHO has stated that all dentists must provide dental care to HIV-positive patients. ${ }^{3}$ Refusement of a dental care of HIV/
AIDS patient is unethical for a dental practioner or a dental student. ${ }^{4}$

Prejudice on HIV causes a serious barrier to effectively fight with the AIDS. There are various reasons for the prejudice toward HIV-infected individuals among general population the most important could be inexact information about the transmission routes of $\mathrm{HIV}^{5}{ }^{5}$

Although the risk of HIV transmission in the dentistry is uncommon, the dental setting has become a suitable place for early detection of oral lesions., ${ }^{6,7}$ Knowledge about the disease course, its oral manifestation and way of transmission influence the students' attitudes and willingness to treat these patients. ${ }^{8}$

Published studies showed that health care workers are lack of knowledge about diagnosis, the treatment and dental care of HIV/AIDS patients appropriately., 90 It was showed that more than half of the medical students thought that treatment of AIDS patients might be dangerous and that their knowledge was not enough to provide dental care effectively.11 Due to increasing number of HIV/AIDS patients, both dental and medical students must be educated well.

There is not any published data about awareness, knowledge level about HIV/AIDS and atti-tudes towards HIV-positive patients among dental students in Yeditepe University, Faculty of Dentistry, and this is the first study to assess this topic. The main objective of the study was to assess the dental students' knowledge level, attitudes and awareness about HIV/AIDS, transmission routes of HIV/ AIDS, diagnosing tests, body fluids contaminated by HIV and intraoral findings of AIDS. And secondary aim was to assess the need for additional education about HIV/AIDS.

\section{MATERIALS AND METHODS}

The International Review Board of University of Yeditepe, Faculty of Dentistry, approved the study. The dental students of academic year of 2013-2014 at Yeditepe University, Faculty of Dentistry were enrolled in the study. Study population consisted of clinically active (clinical) and inactive students (preclinical). Out of 275 students 250 students gave written consent to fill out the survey.

A standardized questionnaire with 77 questions about HIV/ AIDS was developed to evaluate the dental students' level of knowledge (54 questions), sources of information (10 questions), dental students' attitude (10 questions), and need for further education (3 questions). Age, gender and school year were also included in the questionnaire. 


\section{Level of The Knowledge}

\section{A. Knowledge about risk groups of HIV/AIDS}

Knowledge about risk groups of HIV/AIDS was assessed using 10 statements with response scale (1) "true", (0)"false". The students were asked "Is it true or false that healthcare workers, barbers, iv drug users, iv medication users, patients with hemophilia and coagulation disorders, blood transfusion patients, transplantation patients, kids with HIV $(+)$ mothers, homosexual men and heterosexuals with more than one partner are considered as high risk groups "?

\section{B. Knowledge level about potential routes of HIV / AIDS transmission}

Knowledge level about potential routes of HIV/AIDS transmission was evaluated using 10 statements with response scale (1) "true", (0)"false". The students were asked "Is it true or false that "HIV and AIDS can be transmitted by 1) transfusions of infected blood or blood clotting factors, 2) with mosquitoes or insects, 3) HIV-positive women to fetus, 4) breast-feeding, 5) shaking hands or hugging, sharing of towel, glass, fork, knife and etc.. 6) sharp instrument injury, sharing needles and/or syringes (primarily for drug injection) with someone who is infected, 7) dental equipment, 8) barber equipment and 9) unsafe sexual interaction (vaginal, oral, anal) are considered as possible transmission routes"?

\section{Knowledge about diagnosis and screening/ verification tests of HIV/AIDS}

Knowledge about diagnosis and screening/verification tests of HIV /IDS was evaluated using 3 statements with response scale (1) "true", (0) "false". The students were asked "Is it true or false that " ELISA was diagnosing test of HIV/AIDS, 2) Western Blot and 3) Immunofluorescence were screening / verification tests of HIV/AIDS.

\section{Knowledge about body fluids that may transmit HIV}

Knowledge about body fluids that may transmit HIV was evaluated using 10 statements with response scale (1) "true" and (0) "false". The students were asked "Is it true or false that "Body fluids that may transmit HIV 1) Blood, 2) Saliva, 3) Urine 4) Tear, 5) Sweat, 6) Breast Milk, 7) Vaginal secretions, 8) Semen, 9) Feces and 10) Cerebrospinal fluid.

\section{E. Knowledge about oral lesions of HIV}

Knowledge about oral lesions of HIV was evaluated using 20 statements with response scale (1) "true", (0) "false".

\section{Sources of HIV/AIDS related information}

Sources of HIV/AIDS related information were evaluated using 10 questions, "Where do you get information about HIV/AIDS related issues? From 1) media, 2) TV, 3) newspaper, 4) magazine, 5) radio, 6) student courses, 7) friends, 8) family/relatives, 9) brochures, 10) seminar and symposium".

\section{Attitudes}

Ten questions focused on attitudes towards treating HIVpositive patients, legal aspects, the right of healthcare personnel to practice, and willingness to treat. The answer to each question about attitudes was rated on a five-point Likert scale (strongly agree, agree, neutral, disagree, and strongly disagree).

\section{Need for further education}

Three questions assessing education status of dental students and need for further education were "1) Do you think your knowledge about HIV/AIDS is enough? 2) Doyou think you got enough education about HIV/AIDS? 3) Do you want further education about HIV/AIDS? The applicability of the questions was tested on fifty dental students. After evaluation of the data with Cronbach's alpha correlation coefficient, it was suggested that the questionnaire' reliability degree was high ( $\alpha=0.67)$.

Statistical analysis was performed using IBM SPSS Statistics 22 program (IBM SPSS, Turkey). Apart from descriptive statistical methods (mean, standard deviation and percentages), for the comparison of quantitative data, Kruskal Wallis test was used and for detecting the group causing the difference, Mann Whitney $U$ test was used. Continuity (Yates) Correction, Chi square test and Fisher Exact Chi square test were used for the comparison of qualitative data. $A p<0.05$ value was set significant.

\section{RESULTS}

A total of 250 students (response rate, 90.9\%, mean age 21.65 years, 96 (38.4\%) male and 154 (61.6\%) female) participated in the study. Distribution of students' demographic characteristics and school year were shown in Table 1.

Most of the respondents answered correctly the risk groups (Table 2). Patients with hemophilia and coagulation disorders (74\%) and blood transfusion patients (90.8\%) were the less recognized risk groups whereas healthcare workers and IV drug users were the risk groups most frequently recognized. In terms of risk groups, significant difference was not observed between female and male students and preclinical and clinical students. However, 5th 
Table 1: Risk groups of HIV/AIDS

\begin{tabular}{|c|c|c|c|c|c|c|c|c|c|c|c|c|c|}
\hline & & & & & $1^{\text {st } y e a r}$ & $2^{\text {nd }}$ year & $3^{\text {rd }}$ year & $4^{\text {th }}$ year & 5th year & p & Preclinical & Clinical & p \\
\hline & True (\%) & Male n (\%) & $\begin{array}{l}\text { Female n } \\
\text { \%) }\end{array}$ & $\mathbf{P}$ & & n (\%) & $\mathbf{n}(\%)$ & $\mathrm{n}(\%)$ & n (\%) & & n (\%) & n (\%) & \\
\hline Healthcare workers & 98,8 & $94(\% 100)$ & $153(\% 100)$ & - & $47(\% 100)$ & $50(\% 100)$ & $50(\% 100)$ & $50(\% 100)$ & $50(\% 100)$ & - & $97(\% 100)$ & $150(\% 100)$ & - \\
\hline Barbers & 92,8 & $90(\% 93,8)$ & $142(\% 95,9)$ & 10,547 & $47(\% 95,9)$ & $43(\% 89,6)$ & $49(\% 100)$ & $46(\% 93,9)$ & $47(\% 95,9)$ & 0,204 & $90(\% 92,8)$ & $142(\% 96,6)$ & ${ }^{10,229}$ \\
\hline IV drug user & 98,8 & & $152(\% 98,7)$ & 11 & $49(\% 98)$ & $48(\% 96)$ & $50(\% 100)$ & $50(\% 100)$ & $50(\% 100)$ & 0,249 & $97(\% 97)$ & $150(\% 100)$ & ${ }^{10,063}$ \\
\hline IV medication user & 92 & $89(\% 94,7)$ & $141(\% 92,2)$ & ${ }^{2} 0,616$ & $46(\% 97,9)$ & $43(\% 86)$ & $46(\% 92)$ & $47(\% 94)$ & $48(\% 96)$ & 0,17 & $89(\% 91,8)$ & $141(\% 94)$ & ${ }^{20} 0,672$ \\
\hline $\begin{array}{l}\text { Patients with hemophilia \& coagulation } \\
\text { disorders }\end{array}$ & 74 & $71(\% 75,5)$ & $114(\% 78,1)$ & ${ }^{2} 0,763$ & $31(\% 72,1)$ & $35(\% 71,4)$ & $34(\% 70,8)$ & $38(\% 76,0)$ & $47(\% 94)$ & $0,030^{*}$ & $66(\% 71,7)$ & $119(\% 80,4)$ & ${ }^{3} 0,12$ \\
\hline Blood transfusion patients & 90,8 & $89(\% 94.7)$ & $138(\% 97,2)$ & ${ }^{10,489}$ & $35(\% 94,6)$ & $46(\% 92)$ & $49(\% 98)$ & $47(\% 95,9)$ & $50(\% 100)$ & 0,279 & $81(\% 93,1)$ & $146(\% 98)$ & ${ }^{10,079}$ \\
\hline Transplantation patients & 91,6 & $85(\% 93,4)$ & $144(\% 95,4)$ & ${ }^{1} 0,563$ & $44(\% 95,7)$ & $43(\% 91,5)$ & $48(\% 96)$ & $46(\% 93,9)$ & $48(\% 96)$ & 0,839 & $87(\% 93,5)$ & $142(\% 95,3)$ & ${ }^{10,569}$ \\
\hline Kids with HIV $(+)$ mothers & 94 & $91(\% 94,8)$ & $144(\% 95,4)$ & ${ }^{1} 1,000$ & $50(\% 100)$ & $46(\% 95,8)$ & $45(\% 91,8)$ & $44(\% 88)$ & $50(\% 100)$ & $0,019^{*}$ & $96(\% 98)$ & $139(\% 93,3)$ & ${ }^{10,132}$ \\
\hline Homosexual men & 94,8 & $91(\% 94,8)$ & $146(\% 94,8)$ & ${ }^{1} 1,000$ & $48(\% 96)$ & $41(\% 82)$ & $48(\% 96)$ & $50(\% 100)$ & $50(\% 100)$ & $0,001^{* *}$ & $89(\% 89)$ & $148(\% 98,7)$ & ${ }^{2} 0,002$ \\
\hline Heterosexualswithmorethanone partner & 96,4 & $93(\% 96,9)$ & $148(\% 96,1)$ & ${ }^{1} 1,000$ & $49(\% 98)$ & $48(\% 96)$ & $48(\% 96)$ & $50(\% 100)$ & $46(\% 92)$ & 0,28 & $97(\% 97)$ & $144(\% 96)$ & 10,745 \\
\hline
\end{tabular}

${ }^{1}$ Fisher's Exact test

Pearson Chi-Square test

${ }^{1}$ Fisher's Exact test
${ }^{2}$ Continuity Correction (Yates) test

$* p<0,05$

$* * p<0.01$

${ }^{2}$ Continuity Correction (Yates) test
${ }^{3}$ Pearson Chi-Square test

Table 2: Potential transmission routes of HIVIAIDS

\begin{tabular}{|c|c|c|c|c|c|c|c|c|c|c|c|c|c|}
\hline & & & & & & & $3^{\text {rdidyear }}$ & $4^{\text {th }}$ year & $5^{\text {thyear }}$ & & & & \\
\hline & True & Male & Female & $\mathrm{p}$ & $1^{\text {styear }}$ & $2^{\text {nd year }}$ & & & & $\mathrm{p}$ & Preclinical & Clinical & $\mathrm{p}$ \\
\hline & $\mathrm{n}(\%)$ & $\mathrm{n}(\%)$ & $\mathrm{n}(\%)$ & & $\mathrm{n}(\%)$ & $\mathrm{n}(\%)$ & $\mathrm{n}(\%)$ & $\mathrm{n}(\%)$ & $\mathrm{n}(\%)$ & & $\mathrm{n}(\%)$ & $\mathrm{n}(\%)$ & \\
\hline Transmitted with mosquitoes $\mathrm{r}$ insects & 42,4 & $\begin{array}{c}48 \\
(\% 52,2)\end{array}$ & $\begin{array}{c}89 \\
(\% 58,9)\end{array}$ & ${ }^{3} 0,302$ & $\begin{array}{c}21 \\
(\% 45,7)\end{array}$ & $\begin{array}{c}26 \\
(\% 53,1)\end{array}$ & $\begin{array}{c}26 \\
(\% 54,2)\end{array}$ & $\begin{array}{c}32 \\
(\% 64)\end{array}$ & $32(\% 64)$ & 0,305 & $\begin{array}{c}47 \\
(\% 49,5)\end{array}$ & $\begin{array}{c}90 \\
(\% 60,8)\end{array}$ & ${ }^{3} 0,082$ \\
\hline $\begin{array}{l}\text { Transmitted with HIV-positive women to } \\
\text { fetüs }\end{array}$ & 94,8 & $\begin{array}{c}90 \\
(\% 94,7)\end{array}$ & $\begin{array}{c}146 \\
(\% 94,8)\end{array}$ & ${ }^{1} 1$ & $49(\% 98)$ & $\begin{array}{c}49 \\
(\% 98)\end{array}$ & $\begin{array}{c}46 \\
(\% 92)\end{array}$ & $\begin{array}{c}43 \\
(\% 87,8)\end{array}$ & $49(\% 98,0)$ & 0,066 & $\begin{array}{c}98 \\
(\% 98)\end{array}$ & $\begin{array}{c}138 \\
(\% 92,6)\end{array}$ & ${ }^{2} 0,114$ \\
\hline Transmitted with breast-feeding & 55,6 & $\begin{array}{c}48 \\
(\% 51,6)\end{array}$ & $\begin{array}{c}91 \\
(\% 61,5)\end{array}$ & ${ }^{3} 0,131$ & $\begin{array}{c}36 \\
(\% 73,5)\end{array}$ & $\begin{array}{c}31 \\
(\% 63,3)\end{array}$ & $\begin{array}{c}19 \\
(\% 42,2)\end{array}$ & $\begin{array}{c}18 \\
(\% 36,7)\end{array}$ & $35(\% 71,4)$ & $0,001 * *$ & $\begin{array}{c}67 \\
(\% 68,4)\end{array}$ & $\begin{array}{c}72 \\
(\% 50,3)\end{array}$ & ${ }^{3} 0,005^{* *}$ \\
\hline Transmitted with shaking hands or hugging & 4,4 & $\begin{array}{c}87 \\
(\% 94,6)\end{array}$ & $\begin{array}{c}145 \\
(\% 96)\end{array}$ & ${ }^{10} 0,752$ & $\begin{array}{c}45 \\
(\% 95,7)\end{array}$ & $\begin{array}{c}44 \\
(\% 89,8)\end{array}$ & $\begin{array}{c}45 \\
(\% 95,7)\end{array}$ & $\begin{array}{c}48 \\
(\% 96)\end{array}$ & $50(\% 100)$ & 0,194 & $\begin{array}{c}89 \\
(\% 92,7)\end{array}$ & $\begin{array}{c}143 \\
(\% 97,3)\end{array}$ & ${ }^{10} 0,118$ \\
\hline $\begin{array}{l}\text { Transmitted with sharing of towel, glass, } \\
\text { fork, knife and etc. }\end{array}$ & 35,2 & $\begin{array}{c}58 \\
(\% 61,1)\end{array}$ & $\begin{array}{c}102 \\
(\% 66,7)\end{array}$ & ${ }^{3} 0,369$ & $\begin{array}{c}32 \\
(\% 65,3)\end{array}$ & $\begin{array}{c}31 \\
(\% 63,3)\end{array}$ & $\begin{array}{c}35 \\
(\% 70)\end{array}$ & $\begin{array}{c}31 \\
(\% 62)\end{array}$ & $31(\% 62)$ & 0,913 & $\begin{array}{c}63 \\
(\% 64,3)\end{array}$ & $\begin{array}{c}97 \\
(\% 64,7)\end{array}$ & ${ }^{3} 0,951$ \\
\hline $\begin{array}{l}\text { Transmitted with sharp instrument injury, } \\
\text { sharing needles and/or syringes (primarily for } \\
\text { drug injection) with someone who is infected }\end{array}$ & 99,6 & $\begin{array}{c}95 \\
(\% 100)\end{array}$ & $\begin{array}{c}154 \\
(\% 100)\end{array}$ & - & $\begin{array}{c}49 \\
(\% 100)\end{array}$ & $\begin{array}{c}50 \\
(\% 100)\end{array}$ & $50(\% 100)$ & $\begin{array}{c}50 \\
(\% 100)\end{array}$ & $50(\% 100)$ & - & $\begin{array}{c}99 \\
(\% 100)\end{array}$ & $\begin{array}{c}150 \\
(\% 100)\end{array}$ & - \\
\hline Transmitted with dental equipments & 98 & $\begin{array}{c}95 \\
(\% 99,0)\end{array}$ & $\begin{array}{c}150 \\
(\% 97,4)\end{array}$ & ${ }^{1} 0,652$ & $\begin{array}{c}49 \\
(\% 98)\end{array}$ & $49(\% 98)$ & $50(\% 100)$ & $\begin{array}{c}47 \\
(\% 94)\end{array}$ & $50(\% 100)$ & 0,19 & $\begin{array}{c}98 \\
(\% 98)\end{array}$ & $\begin{array}{c}147 \\
(\% 98)\end{array}$ & ${ }^{1} 1,000$ \\
\hline Transmitted with barber equipments & 92,2 & $\begin{array}{c}91 \\
(\% 94,8)\end{array}$ & $\begin{array}{c}134 \\
(\% 90,5)\end{array}$ & 20,334 & $\begin{array}{c}47 \\
(\% 95,9)\end{array}$ & $\begin{array}{c}43 \\
(\% 87,8)\end{array}$ & $48(\% 98)$ & $\begin{array}{c}42 \\
(\% 85,7)\end{array}$ & $45(\% 93,8)$ & 0,108 & $\begin{array}{c}90 \\
(\% 91,8)\end{array}$ & $\begin{array}{c}135 \\
(\% 92,5)\end{array}$ & ${ }^{2} 1,000$ \\
\hline $\begin{array}{l}\text { Transmitted with unsafe sexual intercation } \\
\text { (Vaginal, Oral, Anal) }\end{array}$ & 98,8 & $96(\% 100)$ & $\begin{array}{c}151 \\
(\% 98,1)\end{array}$ & ${ }^{1} 0,288$ & $\begin{array}{c}48 \\
(\% 96) \\
\end{array}$ & $\begin{array}{c}50 \\
(\% 100)\end{array}$ & $49(\% 98)$ & $\begin{array}{c}50 \\
(\% 100) \\
\end{array}$ & $50(\% 100)$ & 0,249 & $\begin{array}{c}98 \\
(\% 98)\end{array}$ & $\begin{array}{c}149 \\
(\% 99,3)\end{array}$ & ${ }^{1} 0,566$ \\
\hline "Fisher's Exact test & ${ }^{2} \mathrm{CO}$ & nity & 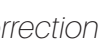 & Yate & test & & ${ }^{3} P \in$ & 70 & yuare test & & & & \\
\hline Pearson Chi-Square test & & $\star p$ & & & $\star * p<0.01$ & & & & & & & & \\
\hline Fisher's Exact test & ${ }^{2} \mathrm{Con}$ & tinuity $\mathrm{C}$ & rectior & Yate & test & & ${ }^{3}$ Pe & $\mathrm{On} C r$ & uare test & *x & 0.05 & & \\
\hline
\end{tabular}

year students recognized correctly patients with hemophilia and coagulation disorders as risk group compared to others. First and fifth year students' knowledge about kids with HIV (+) mothers as risk group was significantly higher compared to fourth year students. Fourth and fifth year students' knowledge on homosexual men as risk group was significantly higher compared to second year students. Almost all of the students had accurate knowledge regarding transmission through transfusions of infected blood or blood clotting factors (99.2\%), transmission by sharp instrument injury, sharing needles and/or syringes (primarily for drug injection) with someone who is infected (99.6\%) and transmission by unsafe sexual intercourse (98.8\%). However, transmission through breastfeeding (55.6\%) and mosquitoes and insects (42.4\%) were less recognized routes of transmission. In terms of potential routes of transmission of HIV/AIDS, significant difference was not observed between female and male students (Table 3) Preclinical and fifth year students showed more accurate knowledge about transmission through breastfeeding compared to others $(p<0.01)$.

In terms of diagnosing tests, although most of the students (82.8\%) gave correct answer as ELISA for the diagnosis of HIV, only 32.8\% of students answered correctly particle agglutination test. Western Blot analysis (57.6\%) and immunofluorescence (44\%) were less recognized as screening/verification tests. In terms of diagnosing and screening/verification tests of HIV/AIDS, significant difference was not observed between male and females, 
Table 3: Body fluids that may transmit HIV

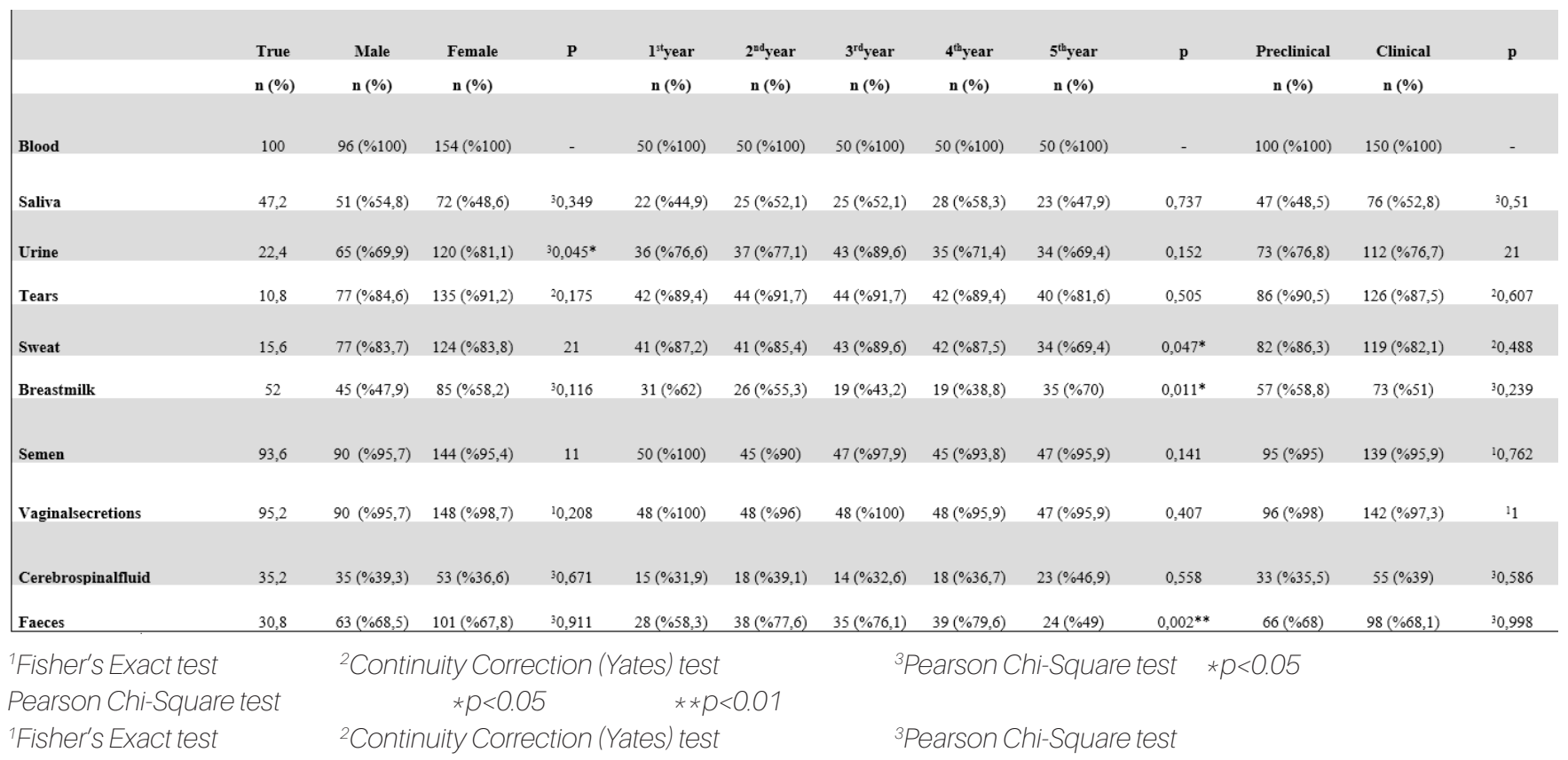

Table 4: Sources of HIV and AIDS related information

\begin{tabular}{|c|c|c|c|c|c|c|c|c|c|c|c|c|c|}
\hline & True & Male & Female & $\mathbf{P}$ & $1^{\text {st }}$ year & $2^{\text {nd }}$ year & $3^{\text {rd }}$ year & $4^{\text {th }}$ year & $5^{\text {th }}$ year & $\mathbf{p}$ & Preclinical & Clinical & p \\
\hline & n (\%) & $\mathrm{n}(\%)$ & $\mathbf{n}(\%)$ & & n (\%) & n (\%) & n (\%) & n (\%) & n (\%) & & $\mathrm{n}(\%)$ & n (\%) & \\
\hline Media & 72 & $72(\% 75)$ & $108(\% 70,1)$ & ${ }^{20} 0,491$ & $46(\% 92)$ & $39(\% 78)$ & $37(\% 74)$ & $29(\% 58)$ & $29(\% 58)$ & $0,001^{* * \pi}$ & $85(\% 85)$ & $95(\% 63,3)$ & ${ }^{1} 0,001^{\text {** }}$ \\
\hline Television & 58,4 & $59(\% 61,5)$ & $87(\% 56,5)$ & ${ }^{10,439}$ & $39(\% 78)$ & $22(\% 44)$ & $36(\% 72)$ & $27(\% 54)$ & $22(\% 44)$ & $0,001^{* *}$ & $61(\% 61)$ & $85(\% 56,7)$ & ${ }^{2} 0,496$ \\
\hline Newspaper & 40,8 & $42(\% 43,8)$ & $60(\% 39,0)$ & ${ }^{1} 0,454$ & $32(\% 64)$ & $15(\% 30)$ & $27(\% 54)$ & $15(\% 30)$ & $13(\% 26)$ & $0,001^{* *}$ & $47(\% 47)$ & $55(\% 36,7)$ & ${ }^{2} 0,103$ \\
\hline Radio & 11,2 & $14(\% 14,6)$ & $14(\% 9,1)$ & ${ }^{2} 0,257$ & $9(\% 18)$ & $1(\% 2)$ & $10(\% 20)$ & $7(\% 14)$ & $1(\% 2)$ & $0,004^{* *}$ & $10(\% 10)$ & $18(\% 12)$ & 10,774 \\
\hline Studentcourses & 76,8 & $67(\% 69,8)$ & $125(\% 81,2)$ & ${ }^{1} 0,038^{*}$ & $27(\% 54)$ & $39(\% 78)$ & $40(\% 80)$ & $40(\% 80)$ & $46(\% 92)$ & $0,001^{* *}$ & $66(\% 66)$ & $126(\% 84)$ & ${ }^{1} 0,002^{* *}$ \\
\hline Friends & 44 & $41(\% 42,7)$ & $69(\% 44,8)$ & 10,745 & $27(\% 54)$ & $19(\% 38)$ & $36(\% 72)$ & $14(\% 28)$ & $14(\% 28)$ & $0,001^{* *}$ & $46(\% 46)$ & $64(\% 42,7)$ & ${ }^{2} 0,603$ \\
\hline Family & 38 & $35(\% 36,5)$ & $60(\% 39)$ & ${ }^{10,692}$ & $23(\% 46)$ & $11(\% 22)$ & $29(\% 58)$ & $16(\% 32)$ & $16(\% 32)$ & $0,002^{* *}$ & $34(\% 34)$ & $61(\% 40,7)$ & ${ }^{2} 0,287$ \\
\hline SeminarandSymposium & 37,2 & $37(\% 38,9)$ & $56(\% 36,4)$ & ${ }^{1} 0,682$ & $11(\% 22)$ & $15(\% 30)$ & $21(\% 42,9)$ & $25(\% 50)$ & $21(\% 42)$ & $0,003^{* *}$ & $26(\% 26)$ & $67(\% 45)$ & ${ }^{2} 0,002^{* *}$ \\
\hline
\end{tabular}

'Pearson Chi-Square test

Pearson Chi-Square test

${ }^{1}$ Continuity Correction (Yates) test
${ }^{2}$ Continuity Correction (Yates) test $\quad * p<0.05$ $* * p<0.01$

2Pearson Chi-Square test and preclinical and clinical students (Table 4).

All of the students answered correctly "blood" as body fluid that may transmit HIV. However, breast milk (52\%) and cerebrospinal fluid (35.2\%) were less frequently reported. In terms of urine as body fluid that may not transmit HIV, male students had significantly less knowledge than females. In terms of sweat as body fluid that may not transmit HIV, first, second, third and fourth year students had significantly better knowledge than fifth year students. Answering correctly breastfeeding as body fluid that may transmit HIV was significantly high at first and last year students $(p<0.05)$. No significant difference was observed between preclinical and clinical students (Table 5).

Oral candidiasis was the most known oral manifestation whereas xerostomia was the less known. Significant difference was not observed between female and male students' knowledge about oral manifestations of AIDS. As shown in Table 6, significant differences were present between students' knowledge level about intraoral findings of HIV/AIDS. Fourth and fifth year students had higher knowledge about oral candidiasis and ANUG than first, second and third year students.

Student courses (76.8\%), media (72\%) and TV (58.4\%) 
Table 5: Responses of dental students to questions about their attitudes toward HIVIAIDS

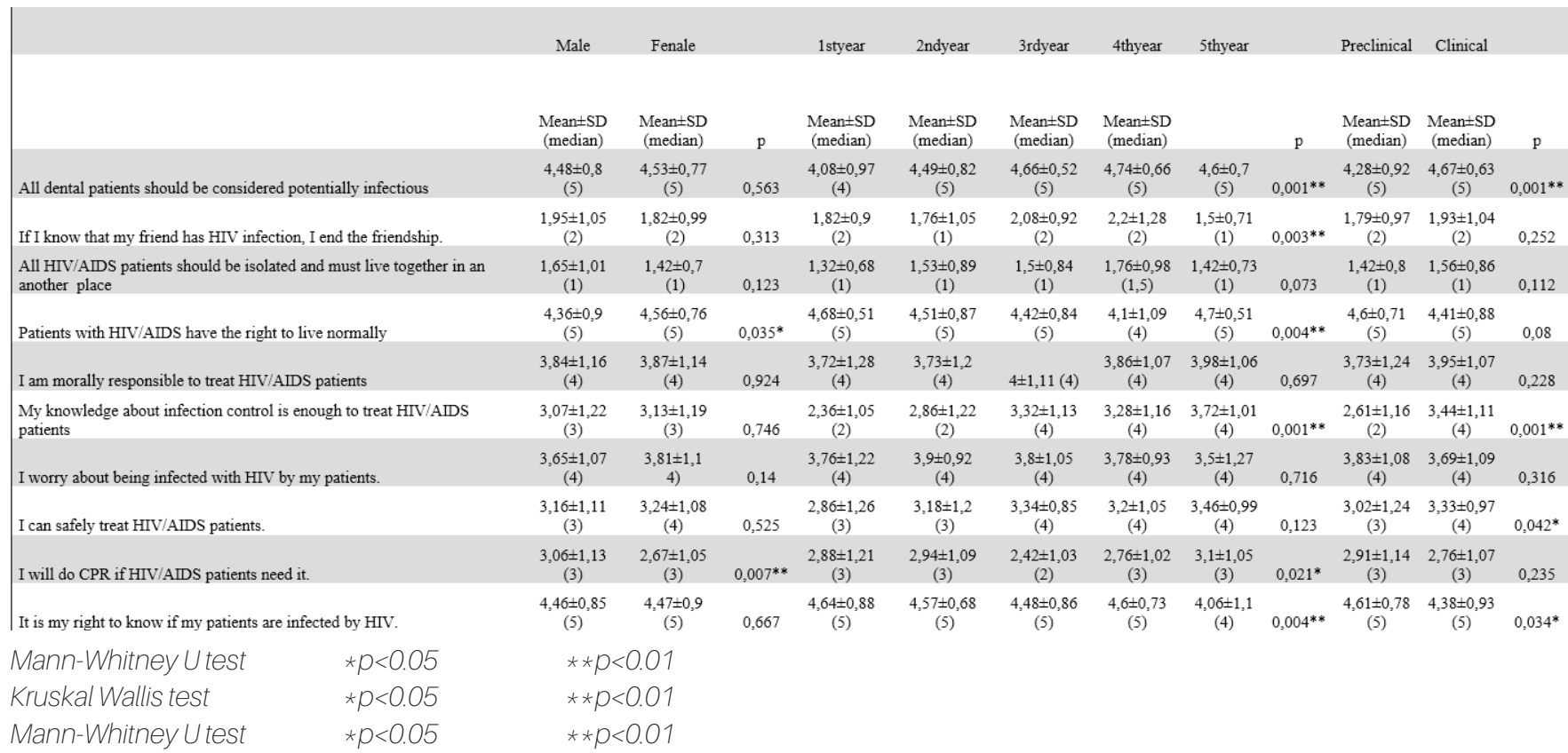

Table 6: Dental students knowledge and education level about HIVIAIDS and need for further education

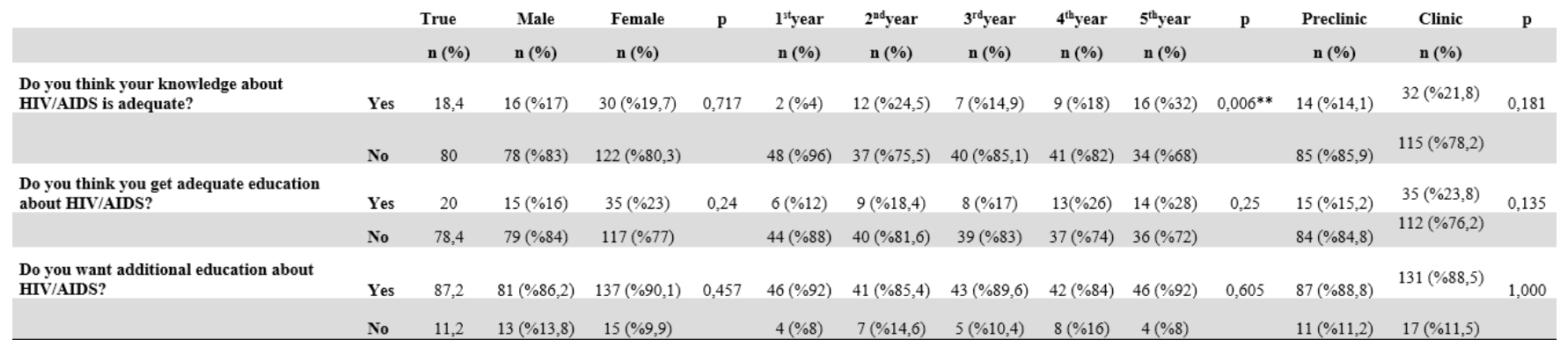

Continuity Correction (Yates) test

Pearson Chi-square test

$* * p<0.01$

Continuity Correction (Yates) test

were the most common answers regarding the sources of information related to HIV/AIDS. Significantly higher female students reported student courses as source of information compared to male students. Except first year students, students received less knowledge from media and newspapers $(p<0.01)$ (Table 7$)$. Clinic students reported student courses and seminars as a source of information than preclinical students $(p<0.01)$ whereas preclinical students reported media as a source of information.

Almost half of the students believed that their knowledge on cross infection is adequate to treat HIV/AIDS patients (Table 8). The statement "If I know that my friend has HIV infection, I end the friendship" obtained the higher positive attitude. While $72.8 \%$ of the respondents were worried about HIV infection from their patients, almost half of the students agreed that they could safely treat HIV/AIDS patients. 90.8\% of the students agreed that HIV infected people should not live in a separate place. $70 \%$ of the students agreed that they were morally responsible to provide dental care to HIVI
AIDS patients. However, of them 28.4\% willing to do CPR on infected patients. The majority of the students (89.6\%) thought that they wanted to know if their patients infected by HIV. 93.6\% of the students agreed with the statement" patients with HIV/AIDs have the right to live normally" and female students had more positive attitude than males Significantly, more male students than female students were self confident about doing CPR to HIV patients. First year students believed that their knowledge about infection control to give dental care to HIV/AIDS infected patients was less than third, fourth and fifth year students.

Eighty percent of the students confirmed that their knowledge and education level about HIVIAIDS was not enough and $87.2 \%$ of the students need further education about HIV/AIDS. No significant difference between female and male students and preclinical and clinical students according to students' knowledge and education level of AIDS. As shown in Table 9, more fifth year students reported that their knowledge and education level about HIV/AIDS 
was enough compared to others.

\section{DISCUSSION}

Although the number of HIV/AIDS patients increases dayby-day, people with HIV are now living longer than before due to progresses in treatment of HIV/AIDS. As part of the health professional team, dental practitioners should improve their knowledge about the disease course disease due to increased dental care needs of people with HIV.12-14

The study population consisted of clinical and preclinical dental students, while most of the similar studies were evaluated only the clinically active dental students. ${ }^{15-19}$ We also aimed to determine if additional information about HIV/ AIDS is needed, which is the reason for selection of our study population. Female predominance observed in the present study was similar to the findings stated by others. ${ }^{18-20}$

In our study, it is important that dental students recognize properly risk group of HIV/AIDS. Most of the students answered correctly the risk groups for HIV infections (94\%). Although health care workers and IV drug users were most frequently recognized at high risk, patients with hemophilia and coagulation disorders and blood transfusion were less known. Although there was no specific gender and school years difference in terms of risk groups, it can be seen that the students in the fifth year recognized correctly patient with hemophilia and coagulation disorders and had better knowledge of homosexual men as risk group compared with other classes. The students' knowledge level about HIV/AIDS risk groups was determined to be very high.

Dental students are at risk of contamination of saliva and blood during dental treatment procedures. Therefore they should have sufficient information about sterilization procedures, cross-infections and barrier techniques. The findings of this study showed that the students believed direct contact with blood to be more infective than saliva. $47.2 \%$ of the students thought that saliva could be a vehicle for transmission of AIDS, which is consistent with the findings of other studies. 19,21,22 In the dental environment, transmission through saliva has not yet been declared ${ }^{4,7,22}$ Similar studies demonstrated that aerosol inhalation during dental treatment believed to be less infective than direct contamination of saliva and blood of HIV infected patients. ${ }^{17,23}$ Moreover, another study comparing dental students' knowledge of two different university revealed that transmission of HIV by blood or saliva contaminated hand pieces were less recognized. ${ }^{16}$ The reason for this may be the rare reports of HIV transmission through this route. 22,24 The majority of the students had adequate knowledge of transmission through blood or blood clotting factors
(99.2\%). However, transmission through breastfeeding (55.6\%), mosquitoes and insects (42.4\%) were less known. Similar findings were reported in other studies. ${ }^{20,23}$ Preclinical and 5th year students showed more accurate knowledge about transmission through breastfeeding compared to 3rd and 4th year students. In fact, breastfeeding may be the main reason causing HIV infections in infants. ${ }^{23}$ These findings are in consistent with another study presenting that last year students of the Nigerian Dental School had better knowledge on HIV transmission routes. ${ }^{17}$

In terms of diagnosing tests, although most of the students (82.8\%) gave correct answer as ELISA, only 32.8\% of students answered correctly particle agglutination test. Western Blot analysis (57.6\%) and immunofluoresencent (44\%) were less recognized as screening/verification tests.

Due to the first symptoms of HIV infection that occur in the oral cavity, dentists have a great possibility to diagnose the symptoms of the disease, which leads to early treatment. In our study; majority of the respondents answer correctly the HIV-associated oral lesions such as oral candidiasis (86.9\%), major aphthous (60.4\%) and herpes simplex (56.4\%), while the condition like condyloma (35.2\%) and xerostomia (34\%) were less known. Except xerostomia, these findings were comparable with a previous study. ${ }^{22}$ While the association between HIV and oral candidiasis was higher than those reported by Al-Naimi et. al. ${ }^{25}$, it was lower than that reported by Bindal et. al. ${ }^{26}$ Fourth and fifth year students' knowledge on oral candidiasis and ANUG were higher than first, second and third year students. This may be due to theoretical lectures about oral symptoms of HIV/AIDS in these years. The present findings suggested that as the level of educational year increased, knowledge about oral manifestations of AIDS increased as well. The dental students knowledge about lesions associated with HIV such as condyloma, verruca vulgaris, salivary gland infections, lichen planus and xerostomia was low.

In the present study, students' courses were the most common reported sources of information regarding HIV/ AIDS. First year students received more information from media and newspapers than others. Our results were in compatible with the results of Nasir et. al. ${ }^{18}$ In a study conducted by Ajavi and Ajavi17, the main sources of information were health workers and textbooks regarding HIV/AIDS, whereas in another study by Grover ${ }^{20}$, electronic media was the main source. The high percentage of media and TV as sources of information does not mean to be improved their knowledge while the quality of sources is questionable.

Majority of the respondents believed thateach patient should be considered potentially infectious. These percentages 
are higher than those reported by others. ${ }^{14,22}$ In case the students are confident of their infection control level, they properly prepare themselves to treat these patients. In the present study, although most of the respondents were afraid of being infected by their patients, nearly half of them declared that they could safely provide dental care of HIV patients. The willingness of students to treat HIV patients was consistent with findings of other studies. ${ }^{12,26,27}$ While these results are higher than those reported by others lower than stated by Fotedar et. al. 19,22,28 Turhan et. al. ${ }^{29}$ reported that the number of dental students who did not want to an AIDS carrier classmate was significantly high; however, the same students reported that they would treat patients with AIDS in their professional life. According to current legislations, dentist must provide dental care to a HIV infected patient. ${ }^{4,19}$ Overestimation of the transmission risk of HIV seemed to be the most important reason for fear in providing dental care to HIV patients. ${ }^{12}$ These fears may cause inability to handle the treatment of HIV infected patients. ${ }^{30}$ Adequate knowledge and positive attitude are the major criteria for treating HIV/AIDS patients. Studies had shown that as the knowledge increases the willingness to treat HIV/AIDS patients increase. $3 ., 4,4,30$

In our study, $28.4 \%$ of students reported that they can do CPR to HIV patients and more male students were selfconfident about doing CPR. These results are extremely higher than those reported by others. 14,19

The results of the present study showed that majority of the students confirmed that their knowledge and education level about HIV/AIDS was not enough and they need further education. Most of the fifth year students reported that their knowledge and education level about HIV/ AIDS was enough compared to others. In case the dental students confident of their knowledge about management of HIV/AIDS patients' treatment, they feel properly prepare themselves to treat these patients.

The students' level of knowledge about HIV in this study was acceptable. However, the students are lack of knowledge about important part of the control and prevention of transmission of HIV/AIDS. These deficiencies were more frequently observed in preclinical students. Considering the student's willingness to treat the HIV positive patients, it was not satisfactory. It is necessary that students be well informed about these infectious diseases and should develop necessary safe practical skills and positive attitude towards treating these patients. Dentists' negative attitudes towards patients with HIV may affect the dental health of HIV infected people.
Moreover, our findings suggested that the curriculum related to knowledge of HIV infection should be carefully examined and improved, beginning from first year and continued in the clinical years. Education on infection control procedures must be increased specifically for preclinical students. In order to prepare future dentists, well equipped with knowledge and positive attitude towards treatment of such patients, health education program is suggested in future to improve their awareness to prevent injuries and to assess the knowledge of universal precaution and their risk perception about these infections. 


\section{REFERENCES}

1. UNAIDS report on the global AIDS epidemic, 2013.At: $\quad$ http://www.unaids.org/sites/default/files/ en/media/unaids/contentassets/documents/ epidemiology/2013/gr2013/UNAIDS_Global_ Report_2013_en.pdf

2. http://www.hatam.hacettepe.edu.tr/veriler. Haziran_2013.pdf

3. Oliveira ER, Narendran S, Falcão A. Brazilian dental students' knowledge and attitudes towards HIV infection. AIDS Care 2002; 14: 569-76.

4. McCarthy GM, Koval JJ, MacDonald JK. Factors associᄀated with refusal to treat HIV-infected patients. the results of a national survey of dentists in Canada. Am J Public Health 1999; 89(4): 541-5.

5. Horizons Program. Measuring stigma: an examplede $\neg$ veloping a stigmaindexin India. At: www.popcouncil. org/Horizons/ORToolkit/toolkit/stigmadevindex1.htm. Accessed: October 5, 2011.

6. Coogan MM, Greenspan JCS. Oral lesions in infection with human immunodeficiency virus. Bulletin of the World Health Organization 2005; 83: 700-706.

7. Borsum KM, Gjermo PE. Relationship between knowledge and attitudes regarding HIV/AIDS among dental school employees and students. Eur J Dent Educ 2004; 8: 105-10.

8. Azodo CC, Ehigiator O, Oboro HO, Ehizele AO, Umoh A, et. al. Nigerian dental students' willingness to treat HIVpositive patients. J Dent Educ 2010; 74(4): 446-52

9. Khandwalla HE, Luby S, Rahman S: Knowledge, attitudes and practices regarding sexually transmitted infections among general practitioners and Medical specialists in Karachi, Pakistan. Sexually Transmitted Infections 2000, 383-85.

10. Shaikh FD, Khan SA, Ross MW, Grimes RM. Knowledge and attitudes of Pakistani medical students towards HIV-positive and/or AIDS patients. Psychol Health Med 2007; 12: 7-17.

11. Kopacz DR, Grossman LS, Klamen DL. Medical students and AIDS: knowledge, attitudes and implicationbs for education. Health Educ Res 1999; 14: 1-6.

12. Hu SW, Lai HR, Liao PH. Comparing dental students knowledge of and attitudes toward hepatitis B virus-, hepatitis C virus-, and HIV-infected patients in Taiwan. AIDS Patient Care STDS. 2004; 18: 587-93.

13. Cohen LA, Romberg E, Grace EG, Barnes DM. Attitudes of advanced dental education students toward individuals with AIDS. J Dent Educ. 2005; 69: 896-900.

14. Aggarwal A, PanatSR. Knowledge, attitude, and behavior in managing patients with HIVIAIDS among a group of Indian dental students. J Dent Educ. 2013; 77: 1209-17.
15. Oberoi SS, Marya CM, Sharma N, Mohanty V, Marwah M, Oberoi A. Knowledge and attitude of Indian clinical dental students towards the dental treatment of patients with human immunodeficiency virus (HIV)/acquired immune-deficiency syndrome (AIDS). Int Dent J 2014, 64(6): 324-32.

16. Ellepola AN, Joseph BK, Sundaram DB, Sharma PN. Knowledge and attitudes about HIVIAIDS of dental students from Kuwait and Sri Lanka.Eur J Dent Educ 2011: 15: 165-71.

17. Ajayi YO, Ajayi EO. Dental students' knowledge of human immunodeficiency virus. J Dent. 2008; 36: 374 8.

18. NasirEF, Astrøm AN, David J, Ali RW. HIV and AIDS related knowledge, sources of information, and reported need for further education among dental students in Sudan-a cross sectional study. BMC Public Health. 2008; 14: 8. 286

19. SadeghiM, HakimiH. Iranian dental students' knowledge of and attitudes towards HIV/AIDS patients. J Dent Educ. 2009; 73: 740-5

20. Grover $N$, Prakash A, Singh S, Singh N, Singh $P$, NazeerJ. Attitude and knowledge of dental students of National Capital Region regarding HIV and AIDS. J Oral MaxillofacPathol. 2014; 18: 9-13.

21. Kemppainen $J K$, Dubbert PM, McWilliams P: Effects of group discussion and guided patient care experience on nurses' attitudes towards care of patients with AIDS. J AdvNurs 1996; 24: 296-302

22. Alsamghan AS. Knowledge and attitude of male dental students toward HIVIAIDS in King Khalid University, Saudi Arabia. International Journal of Public Health and Epidemiology 2012; 1:001-009

23. Ellepola, A. N., Sundaram, D. B., Jayathilake, S., Joseph, B. K., \& Sharma, P. N. Knowledge and attitudes about HIV/AIDS of dental students from Kuwait and Sri Lanka. Journal of Dental Education 2011; 75: 574-581.

24. Blignaut E. The role of the dental profession in the AIDS epidemic: practitioner corner. J Dent Assoc S Afr 1994, 49: 113-52.

25. Al-Naimi RJ.,Al-Saygh GD. . Knowledge,attitude and health behavior of dental students towards HIV/AIDS patients. Al-Rafidain Dent J. 2009; 9: 110-119.

26. Bindal P, Bindal U, Dental Students' Perceptions on Patients with HIV or Hepatitis B Infection. Annual Research \& Review in Biology 2014; 4: 3645-3655,

27. Oboro HO, Azodo CC, Sede MA. Perception of HIV/AIDS patients among pre-clinical dental students. Int J Infect Dis 2008; 12: e158.

28. Fotedar S, Sharma KR, Sogi GM, Fotedar V, Chauhan A. 
Knowledge and attitudes about HIV/AIDS of students in H.P. Government Dental College and Hospital, Shimla, India. J Dent Educ. 2013; 77(9): 1218-24.

29. Turhan O, Senol Y, Baykul T, Saba R, Yalçin AN Knowledge, attitudes and behaviour of students from a medicine faculty, dentistry faculty, and medical technology Vocational Training School toward HIVI AIDS.Int J Occup Med Environ Health. 2010; 23(2): 15360. doi: 10.2478/v10001-010-0008-5.

30. Erasmus S, Luiters S, Brijlal P. Oral hygiene and dental students' knowledge, attitude, and behaviour in managing HIV/AIDS patients. Int J Dent Hyg 2005; 3(4): 213-7. 